\title{
Comparative Studies Between Zinc Phosphide and Oshar Leaves Extract As A Rodenticide Against Norway Rat Rattus Norvegicus (Berkenhout) Under Laboratory and Field Conditions \\ Eisa, Y. A. E. and E. M. A. Yassin \\ Plant Protection Research Institute, Agricultural Research Center, Dokki, Giza, Egypt
}

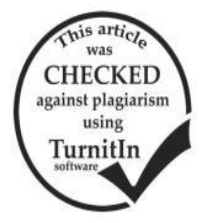

\section{ABSTRACT}

The rodenticidal effect of ethanolic leaves extract of Oshar, Calotrips procera (Ait.) was studied comparatively with zinc phosphide under laboratory and field conditions at (Qaha region) Qaluobia Governorate against the Norway rat, Rattus norvegicus (Berkenhout). Results showed that zinc phosphide was more toxic than Oshar extract whereas the acute oral $\mathrm{LD}_{50}$ values were 0.27 and $88.0 \mathrm{mg} / \mathrm{kg}$ b.w., respectively. The efficiency test showed that in non-choice and free-choice feeding test a bait containing $1 \%$ either zinc phosphide or Oshar plant extract gave $100 \%$ mortality with short time to death for zinc phosphide treatment. Oshar bait was more palatable to mice than zinc phosphide with 56.2 and $40.6 \%$ bait acceptance, respectively. Under the field condition, zinc phosphide caused $78.45 \%$ reduction whereas Oshar plant extract reduced $66.5 \%$ the population of the Norway rat, respectively.

\section{INTRODUCTION}

Rodents are very common animals in many Egyptian governorates, Shoukry et al., (1986), Morsy et al., (1988) and considered as one of the most important pest groups in Egypt. Beside their economic hazard causing damage to agriculture and problems and contamination of stored food materials. They also play an important role as reservoir host for many zoonotic diseases such as plaque and murine. Also, they cause great economic losses to growing and stored crops, poultry and animal farms, food manufactories as well as structure and fabric of buildings. Anticoagulants compounds are generally effective against most rodents species, when used with surplus baiting although long periods of feeding may be required in some cases. However, some species e.g. the Egyptian spiny mouse, Acomys cahirinus and the house mouse, Mus musculus have a naturally low sensitive to certain anticoagulants and their use would almost certainly lead to control failure (Gill, 1992). In this respect, the sequential treatments of acute poisone fallowed by the anticoagulants was recommended to achieve good control success (Mahmoud and Rennison 1986). Zinc phosphide is the most commonly used acute rodenticide and has a relatively long history of use and it is becoming a standard to compare with newly developed rodenticides (Meehan, 1984).The search for naturally occurring pesticides had in a discovery of some plantderived compounds that are active against pest species, although their commercial viability is yet to be established. Oshar plant Calatropis procera is a common plant containing natural constituents with different biological properties (Lin et al., 1996). The use of toxic plants is especially prevalent in the developing countries, where plants grown locally are cheaper than the synthetic chemical pesticides (El-Gengaihi et al., 1997).The present work aims to study the laboratory toxicity and field preference of zinc phosphide and Oshar plant extract against $R$. norvgicus as one of the most widely distributed rodent species.

\section{MATERIALS AND METHODS}

\section{Tested compounds:}

Zinc phosphide.Technical grade zinc phosphide (94\% active ingredient) was obtained from Kafr ElZayat (Kz) Pesticide Company, Egypt.

Oshar leaves extract. Oshar plant Calotrips procera was obtained from Aswan Governorate and extracted by ethanol as follows: Oshar leaves were dried and grounded with a mill into fine powder and sieved through $400 \mathrm{M}$ sieve. One hundred gram of sieved powder was macerate in $500 \mathrm{ml}$ of absolute ethanol for three days. The extract was filtered through filter paper satisfied with $2 \mathrm{~g}$ anhydrous sodium sulphate and the filtrate was evaporated by rotary evaporate under vacuum at $50{ }^{\circ} \mathrm{C}$. The ethanolic Oshar crude extract was weighted and kept frozen at $-20{ }^{\circ} \mathrm{C}$ as stocked till required, (Freedman et al., 1979).

Tested animals:

Adult individuals of the Norway rat, R.norvegicus were trapped from field at Qaha district, Qaluobia Governorate. Animals were transported to the laboratory, and weighted. Animals were retained individually caged for three days acclimatization and fed on a standard $(65 \%$ crushed maize $+25 \%$ ground wheat $+5 \%$ sugar $+5 \%$ corn oil) and water. The sick and pregnant animals were eliminated.

\section{Determination of $\mathbf{L D}_{50}$ :}

Acute oral $\mathrm{LD}_{50}$ of zinc phosphide and Oshar crude extract were determined. Animals of the Norway rat were fasted for about $12 \mathrm{~h}$ before treatment. Serial doses of both compounds were measured as $\mathrm{mg} / \mathrm{kg}$ body weight and mixed with small amount of vegetable oil and orally administered to the animals using stomach tubes, and then water and diet were offered 2 hours after treatment. Five animals were used for each dose. A parallel control test was conducted using plain vegetable oil. Mortality and time to death were recorded up to 4 and 10 days post-zinc phosphide and Oshar treatments, respectively. Dead animals were aulopsied to confirm symploms of poisoning. $\mathrm{LD}_{50}$ values were calculated using special tables given by Horn (1956). 
Evaluation of zinc phosphide and Oshar extract as rodenticides:

Non choice feeding method:

A group of 10 Norway rat individually caged were used per each treatment. Each mouse was offered $20 \mathrm{~g}$ of crushed maize containing either $1 \%$ zinc phosphide or $1 \%$ Oshar plant extract. In addition, another group was offered plain crushed maize as check control. The consumed amount of treated bait was recorded daily for 4 successive days then the treated bait was removed. The survivor animals were fed on the standard diet and observed for 28 days. During this period, mortality was recorded and animals were autopsied to observe the symptoms of poisoning.

Free choise feeding method:

The free choice feeding method according to Palmateer (1974) was used to determine the poisoned bait acceptance by comparing its consumption with that of standard challenge diet. Group of 10 animals caged individually were used for each compound and another one as cheek control. Each rat was affected $20 \mathrm{~g}$ of crushed maize containing either $1 \%$ zinc phosphide or $1 \%$ Oshar extract and $20 \mathrm{~g}$ standard challenge diet in small separate dishes. The position of the two dishes was altered daily to avoid feeding preference for a certain location. The consumed amount of the poisoned bait and standard diet was recorded daily for 4 successive days then the poisoned bait was removed and the survivor animals were fed on the standard diet. Dead animals were counted daily up to 28 days. Bait acceptance was recorded as follows:

Acceptance $\%=$ Consumed amount of treated bait $x 100$

Field performance:

Consumed amount of treated bait + standard diet

Field evaluation of crushed maize bait contains either $1 \%$ zinc phosphide and $1 \%$ Oshar extract was carried out under the field conditions of Qaha district, Qaluobia Governorate. An infested area with the Norway rat, R.norvegicus was chosen and divided into 5 plots, each of one feddan. Two plots were chosen for each compound and one plot was left without treatment as cheek control. The population density of $R$. norvgicus was estimated pre- and post-treatment using food consumption method accrding to Dubock (1984). Two kilograms of the candidate bait were packed into plastic sacks each contained 50 gram and distributed in the chosen plot for one week. The consumed amount of each tested bait was recorded. The percentage of population reduction was calculated as follows:

Population reduction $\%=\underline{\text { (Pre-treatment)- (post-traetment census) }} \times 100$ Pre-treatment census

\section{RESULTS AND DISCUSSION}

\section{Acute oral toxicity:}

It has become a common practice to use $\mathrm{LD}_{50}$ values for express and compare the toxicity of different pesticides. Data in Table (1) showed that the dose of zinc phosphide (rodenticide) 0.16, 0.19, 0.23, 00.27, 0.33 and $0.39 \mathrm{mg} / \mathrm{kg}$ caused $0.20 \%, 40 \%, 60 \%, 80 \%$ and $100 \%$ mortality, respectively. Treated and calculated $\mathrm{LD}_{50}$ values were $0.27 \mathrm{mg} / \mathrm{kg}$ whereas the doses of Oshar crude plant extract 21.5, 46.4, 100.0 and $215.0 \mathrm{mg} / \mathrm{kg}$ caused $20 \%, 20 \%, 60 \%$ and 80.5 mortality, respectively. Treated and calculated $\mathrm{LD}_{50}$ values were $88.0 \mathrm{mg} / \mathrm{kg}$. The average time to death was decreased with increasing the dose of both compound whereas it was 16 and $36 \mathrm{~h}$ at dose level of 0.27 and $46.4 \mathrm{mg} / \mathrm{kg}$ and reached to 12 and $28 \mathrm{~h}$ at dose level of 0.39 and $100 \mathrm{mg} / \mathrm{kg}$ for zinc phosphide and Oshar crude extract, respectively. The obtained results clear that on the bases of $\mathrm{LD}_{50}$ values, zinc phosphide and Oshar extract proved to be effective against the Norway rat, however, zinc phosphide was more toxic. These findings are in harmony with those of Caughley et al, (1998) who mentioned that, the acute oral $\mathrm{LD}_{50}$ of zinc phosphide for house mice, Mus domesticus was 32 $\mathrm{mg} / \mathrm{kg} \mathrm{b}$. w. and death occurs within a few hours of ingestion.

Table (1): Acute oral toxicity of zinc phosphide and Oshar extract to the Norway rat, $R$. norvegicus

\begin{tabular}{|c|c|c|c|c|c|c|}
\hline \multirow{2}{*}{ Compound } & \multirow{2}{*}{ Group No. } & \multirow{2}{*}{ Dose mg/ kg. } & \multirow{2}{*}{ mortality } & \multicolumn{3}{|c|}{ Time to death } \\
\hline & & & & Range & Mean & $\mathrm{LD}_{50} \mathrm{mg} / \mathrm{kg}$ \\
\hline \multirow{6}{*}{ Zinc phosphide } & 1 & 0.16 & $0 / 5$ & - & - & \multirow{6}{*}{$0.27 \mathrm{mg} / \mathrm{kg}$} \\
\hline & 2 & 0.19 & $0 / 5$ & - & - & \\
\hline & 3 & 0.23 & $1 / 5$ & - & 18 & \\
\hline & 4 & 0.27 & $2 / 5$ & $8-24$ & 16 & \\
\hline & 5 & 0.33 & $3 / 5$ & $4-22$ & 15 & \\
\hline & 6 & 0.39 & $4 / 5$ & $6-18$ & 12 & \\
\hline \multirow{4}{*}{ Oshar extract } & 1 & 21.5 & $1 / 5$ & - & 48 & \multirow{4}{*}{88.0} \\
\hline & 2 & 46.4 & $1 / 5$ & - & 36 & \\
\hline & 3 & 100.0 & $3 / 5$ & 24.36 & 28 & \\
\hline & 4 & 215.0 & $4 / 5$ & 12.48 & 28 & \\
\hline
\end{tabular}

\section{Evaluation of zinc phosphide and Oshar extract as rodenticides:}

Laboratory performance: Data in Table (2) showed that in non-choice feeding test a bait containing either $1 \%$ zinc phosphide or $1 \%$ Oshar extract gave complete mortality with average bait consumption of 2.1 and $3.8 \mathrm{~g} /$ Norway rat, respectively. A considerable variation in the time to death was observed whereas it ranged 6-18 $\mathrm{h}$ with an average of $12 \mathrm{~h}$ for zinc phosphide and ranged between 18-60 h with an average of $32 \mathrm{~h}$ for Oshar extract. The palatability and efficacy of $1 \%$ zinc phosphide and Oshar extract were tested using free choice method, data in Table (3) indicated that both compounds induced complete mortality $100 \%$ 
regarding the mean time required to death, results revealed that it was $15 \mathrm{~h}$ for zinc phosphide and $42 \mathrm{~h}$ for ethanolic Oshar extract. On the other hand, Oshar bait was more palatable to Norway rat than zinc phosphide with 56.2 and $40.6 \%$ bait acceptance, respectively. Reviewing the aforementioned results, it is obvious that both compounds proved to be efficient to house mouse, however, zinc phosphide was more effective. Asran (1994) mentioned that $1 \%$ zinc phosphide bait gave complete mortality of the mouse, Mus musculus in choice and non-choice feeding methods. The palatability of the tested animals had a negative correlation with the used concentration and the palatability of Arvicanthis niloticus to zinc phosphide at 1.2 and $3 \%$ was $38.5,21.7$ and $17.66 \%$, respectively. Also, in non-choice and free choice feeding tests, bait containing $1 \%$ Oshar leaves gave $100 \%$ mortality of albino rat, Rattus norvgicus followed by Oshar extract by hexane and petroleum ether, while the water extraction had the lowest effect (Gabr et al., 2004).

Table (2): Effect of bait containing $1 \%$ zinc phosphide and $1 \%$ Oshar extract against the Norway rat $R$. norvegicus for 4 successive days using non choice method

\begin{tabular}{lcccc}
\hline Compound & $\begin{array}{c}\text { Average bait consumption } \\
(\text { g) Norway rat }\end{array}$ & \multirow{2}{*}{ Mortality } & \multicolumn{2}{c}{ Time to death } \\
& 2.1 & 100 & $6-18$ & Mean \\
\hline Zinc phosphide & 3.8 & 100 & $18-60$ & 12 \\
Oshar extract & & & 32 \\
\hline
\end{tabular}

Table (3); Effect of bait containing $1 \%$ zinc phosphide or $1 \%$ Oshar extract against the Norway rat $R$. norvgicus for 4 successive days using free choice method

\begin{tabular}{lcccc}
\hline \multirow{2}{*}{ Compound } & Acceptance & Mortality & \multicolumn{2}{c}{ Time to death (h) } \\
& $\boldsymbol{\%}$ & $\boldsymbol{\%}$ & Range & Mean \\
\hline Zinc phosphide & 40.6 & 100 & $6-22$ & 15 \\
Oshar extract & 56.2 & 100 & $18-70$ & 42 \\
\hline
\end{tabular}

\section{Field performance:}

The efficiency of $1 \%$ zinc phosphide and $1 \%$ Oshar extract bait was tested against the rat, $R$. norvegicus under the field conditions of the same region mentioned before. Results in Table (4) show that zinc phosphide caused $78.40 \%$ reduction whereas Oshar extract $66 \%$ reduction of the rat population was recorded. The average of bait consumption was $648 \mathrm{~g}$ per feddan, for zinc phosphide, while it was $862 \mathrm{~g}$ for Oshar extract. One the light of the obtained results Oshar extract proved to be promising compound that can be effectively used as a rodenticide in comparison with zinc phosphide. El-Deeb et al., (1991) found that $1.5 \%$ zinc phosphide gave 64 and $70 \%$ reduction of Arvicanthis niloticus (Geoffrey) and Meriones shawi (Duvernoy), respectively. El-Sebaii (1996) indicated that powdered Oshar with $\mathrm{LD}_{50}$ of $82 \mathrm{mg} / \mathrm{kg}$ b.w. baited with crushed maize at different ratios proved to have strong lethal effect against rats. On the other hand, Ibrahim (2001) reported that $\mathrm{LD}_{50}$ and $\mathrm{LD}_{90}$ value of Oshar leaves extract to $R$. norvgicus are 89 and 148 $\mathrm{mg} / \mathrm{kg}$, respectively. He added that Oshar extract reduced $85.3 \%$ of rat population. Rizk (2006) found that the poisoned bait of zinc phosphide $2.5 \%$ lost $20 \%$ and $50 \%$ of its effectiveness when exposed to $80 \%$ R.H. for 2 and 7 days, respectively. El-Deeb et al., (2011) noticed that golden a shower ethanol extract proved to be promising compound that come to be effectively used as a rodenticide in comparison with zinc phosphide. The rodenticidal effects of seven crude plant extracts were studied under laboratory and field conditions by Abou-Hashem (2012).The results revealed that only three extracts, particularly those extracted by ethanol, promised to be used as a rodenticide against $R$. norvegicus. These are calendula, sumac and camphor extracts.

Table (4): Field performance of zinc phosphide and Oshar extract against the Norway rat, $R$ norvgicus at (Qaha region) Qaluobia Governorate

\begin{tabular}{lcccc}
\hline \multirow{2}{*}{ Compound } & \multicolumn{2}{c}{ Average consumption (g/feddan) } & \multicolumn{2}{c}{ Population } \\
& Pre-treatmnet & Poisonous bait & Post-treatmnet & reduction \% \\
\hline Zinc phosphide & 463 & 648 & 100 & 78.4 \\
Oshar extract & 457 & 862 & 155 & 66.0 \\
control & 452 & - & 461 & 0 \\
\hline
\end{tabular}

\section{REFERENCES}

Abou-Hashem, A. A. M. 2012. Evaluation of the rodenticidal effects of some plant extracts under laboratory and field conditions. The Journal of Basic \& Applied Zoology, 65: 282-288.

Asran, A.A. 1994. Susceptibility and palatability of some Egyptian rodents to zinc phosphide. Agric. Res. Rev., 72 (1): 141-145.
Caughley, J.; M. Bomford; B. Parker; R. Sinclair; J. Griffiths and D. Kelly 1998. Managing vertebrate pests: rodents. Canberra, Bureau of Resource Sciences.

Dubock, A. C. 1984. Pulsed baiting-a new technique for high potency, slow acting rodenticides. Proc. Conf. of the organization and practice of vertebrate pest control, U.K., 105-143. 
El-Deeb, H.I.; M. D. Abdallah; M. A. Kandil and W. H. Gabr 1991. Laboratory and filed studies with zinc phosphide on different rodent species. $4^{\text {th }}$ Arab. Cong. Plant Prot. Cairo, 1-5 Dec., pp. 494-499.

El-Deeb. H.I.; I. K. Ibrahim; Fatma K. Khidr and A. A. Abo-Hashem 2011.Comparative studies between zinc phosphide and golden a shower crude seeds plant extract as a rodenticide under laboratory and field conditions. J. Plant Prot. and Path., Mansoura Univ.,2 (4): 421 - 428.

El-Sebaii, A. M. 1996. Evaluation of the efficacy of some new compounds as pesticides. Ph. D. Thesis, Fac. Agric., Alex. Univ.

EL-Gengaihi, S. E., N.Z., Dimetry and S.M., Mohamed 1997. Chemical and biological investigation of harmal plant.2-Alkaloidal investigation. J. Appl. Entomol. 12 (3), 165-167.

Freedman, b.J.; J. Nowak and W.F. Kwolek 1979. A bioassay for plant derived pest control agent using the European Comborer. J. Econ. Entomol., 72: $45-54$.

Gabr, W.M.; F.K. Khidr, and A. M. Hegab 2004. Evaluation of Oshar crude plant extract as a rodenticide under laboratory and field conditions. Zagazig J. Agric. Res. 31 (4A), 1607-1616.

Gill, J. E. 1992. A review of the results from laboratory tests of some rodenticieds against eight rodent species. Proc. $15^{\text {th }}$ Vertb. Pests Conf. Davis Univ. California, U.S.A.: 182-191.

Horn, H. G. 1956. Simplified $\left(\mathrm{LD}_{50}\right.$ or $\left.\mathrm{ED}_{50}\right)$ calculation. Biometrics, 12: 311-322
Ibrahim, I. K. 2001. Effect of some wild plant extracts as rodenticidal properties on certain rodent species.Ph.D.Thesis.Fac.Agric.Al-Azhar University.

Lin, R.G.;S. Guthric; M.D.Y. Lee and T. K. Lumeng 1996. Isoflavonoid compounds extract from Puevaria lobata suppress alcohol preference in a a pharmacokinetic rat model of alcoholism. Clin. And Exp. Res., 20 (4): 659-663.

Mahmoud, W. and B.D. Rennison 1986. The responses of commensal rodents in Egypt villages to control with $0.002 \%$ brodifacoum, 0-1\% calcifral and zinc phosphide. Proc. $2^{\text {nd }}$ Symp. On rodent advances in rodent control, Kuwait, 233-239.

Meehan, A. P. 1984. Rats and mice, their biology and control. $1^{\text {st }}$ Ed. Rentokil limited.Flecourt.East Grainstead,W.SussXRH.192:249-251.

Morsy, T.A.; A. Shoukry and G.A. El-Kady 1988.A review and distribution map of rodents in Sinai, Egypt. J. Egypt. Soc. Parsitol., 18, 2: 683-692.

Palmateer, S. D. 1974. Laboratory testing of albino rats with anticoagulant rodenticides Proc. $6^{\text {th }}$ Vert. Pest Conf., Anaheim. Calif. March 5-7; 63-72

Rizk, A.M. 2006. Teratogenic effect and biochemical changes due to some rodenticide on certain rodent species. Ph.D. Thesis, Fac. Agric. AlAzhar Univ.,

Shoukry, A.; T. A. Morsy; I.A.Abu Hashish and G. A. El-Kady 1986. Seasonal activities of two commernsal rats and index in North Sinai, Egypt. Soc.Parasitol., 16: 385-393.

\section{دراسـات مقارنـة بين مبيد فوسفيد الزنكك ومستخلص اوراق نباتـات العشـاركمبيد قوارض تحت الظروف المعلية والحقلية على الفار النرويجى Rattus norvegicus

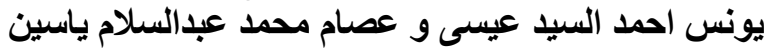

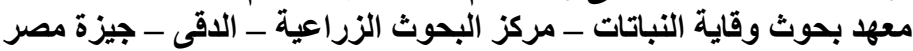

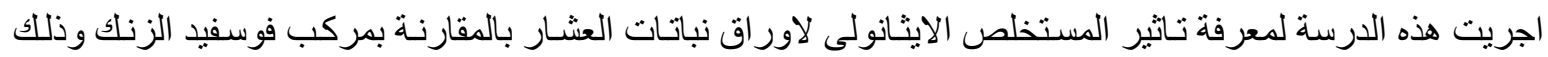
تحت الظروف المعملية والحقلية فى محافظة القليوبية (منطقة قها) ضد الفار النرويجى Rattus norvgicus حيث دلت الت النتائج

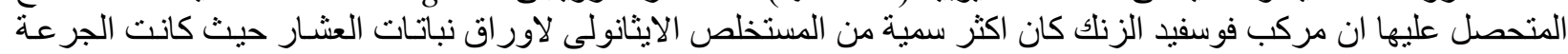
تحت المميتة

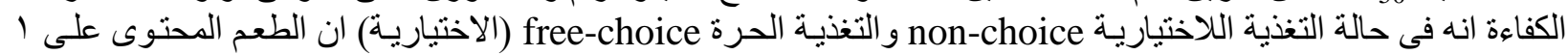

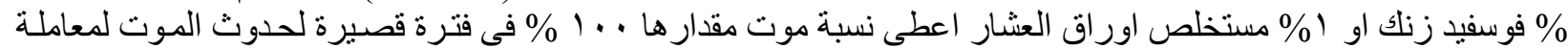

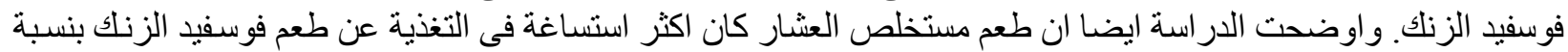

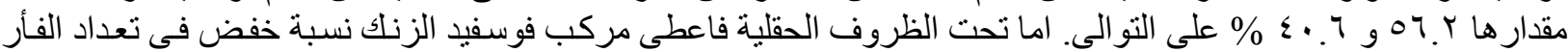

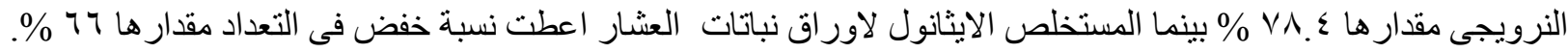

